\title{
KOMPARASI PERPADUAN SIR 20/SBR DAN SIR 3CV/BR SEBAGAI BASE ELASTOMER TERHADAP KARAKTERISTIK KOMPOSIT KARET UNTUK TELAPAK BAN PEJAL VULKANISIR
}

\author{
Comparison of SIR 20/SBR and SIR 3CV/BR Mixture as Base Elastomer to the \\ Characteristic of Rubber Composite for Retread Solid Tire \\ NURJANNAH ${ }^{1}$, Novi WIDIANTI ${ }^{1}$, Norma Arisanti KINASIH ${ }^{2}$, \\ Santi PUSPITASARI ${ }^{2}$, dan Adi CIFRIADI ${ }^{2}$ \\ ${ }^{1}$ Departemen Teknik Kima, Politeknik STMI \\ Jalan Letjen Suprapto No. 26 Jakarta Pusat 10510 DKI Jakarta \\ ${ }^{2}$ Balai Penelitian Teknologi Karet, Pusat Penelitian Karet \\ Jalan Salak No. 1 Bogor 16128 Jawa Barat \\ *Email : puspitasari.santi@puslitkaret.co.id
}

Diterima : 25 Agustus 2020 / Disetujui : 10 November 2020

\begin{abstract}
The retread tire industry plays important role in developing national downstream rubber agroindustry. Tire tread is the main part to be evaluated in determining retread tire quality. The mixture of natural and synthetic rubbers is often be used in designing tread rubber compound formula. The research was aimed to study the usage of a rubber mixture such as SIR 20/SBR and SIR $3 C V / B R$ as base elastomer in the fabrication of rubber composite for retread solid tire for forklift wheels. The ratio of rubber mixtures was arranged as 75/25; 70/30; and 65/35, meanwhile the quantity of all the rubber chemicals were remains constant for all experimental conditions. The quality of solid tire tread was investigated based on the physical and mechanical test results, such as hardness, tensile strength, elongation at breaks, tear strength, flex cracking resistance, and ozone resistance. The result of the analysis indicated that SIR 20/SBR had better performance compared to SIR $3 C V / B R$. The ratio of SIR 20/SBR at 75/25 was selected as the most optimum composition since the mixture resulted in the highest value of hardness (57 Shore A), tensile strength $\left(23.77 \mathrm{~N} / \mathrm{mm}^{2}\right)$, elongation at breaks $(570 \%)$. Therefore, the tear strength $(29.7 \mathrm{kN} / \mathrm{m})$ and flex cracking resistance (80 $\mathrm{kCs})$ of the mixture should be enhanged.
\end{abstract}

Keywords: rubber composite; rubber mixture; solid tire; tire tread

\begin{abstract}
Abstrak
Industri ban vulkanisir turut berperan penting dalam menggerakan agroindustri hilir karet di dalam negeri. Telapak ban menjadi bagian utama dalam menentukan mutu ban vulkanisir. Perpaduan karet alam dengan karet sintetik sering kali digunakan dalam merancang formulasi kompon karet untuk pembuatan telapak ban. Penelitian ini mengkaji penggunaan perpaduan karet alam/karet sintetik jenis SIR 20/SBR dan SIR 3CV/BR dalam mempersiapkan komposit karet untuk telapak ban pejal pada roda forklift vulkanisir. Perpaduan karet alam/karet sintetik diatur pada komposisi 75/25; $70 / 30$; dan 65/35, sementara seluruh dosis bahan kimia karet ditetapkan sama pada semua kondisi percobaan. Mutu telapak ban pejal yang diperoleh dievaluasi berdasarkan hasil pengujian parameter kekerasan, kuat tarik, perpanjangan putus, ketahanan sobek, ketahanan retak lentur, dan ketahanan ozon. Hasil karakterisasi sifat fisika dan mekanik komposit karet untuk telapak ban pejal vulkanisir menunjukkan bahwa secara umum perpaduan karet SIR 20/SBR memiliki performa yang lebih baik dibandingkan perpaduan karet SIR 3CV/BR. Rasio SIR 20/SBR sebesar 75/25 dipilih sebagai komposisi teroptimum karena menghasilkan nilai kekerasan (57 Shore A), kuat tarik $\left(23,77 \mathrm{~N} / \mathrm{mm}^{2}\right)$, perpanjangan putus $(570 \%)$ yang tertinggi. Meskipun demikian nilai ketahanan sobek
\end{abstract}


$(29,7 \mathrm{kN} / \mathrm{m})$ dan ketahanan retak lentur $(80$ $\mathrm{kCs}$ ) pada perpaduan karet tersebut masih perlu ditingkatkan.

Kata kunci : ban pejal; komposit karet; perpaduan karet; telapak ban

\section{PENDAHULUAN}

Industri manufaktur ban kendaraan bermotor mengkonsumsi sekitar $70 \%$ dari total produksi karet alam dunia (Gould, 2015). Keberadaan karet alam sebagai material polimer penyusun ban kendaraan tidak dapat digantikan oleh karet sintetik, namun antar kedua material tersebut justru saling dipadukan agar dapat diperoleh kualitas ban kendaraan yang unggul dan dapat memenuhi standar. Tipe karet alam yang paling dominan digunakan dalam pembuatan ban kendaraan adalah SIR 20, sedangkan dari golongan karet sintetik adalah styrene butadiene rubber (SBR) dan polybutadiene rubber (BR). Karet alam dikenal memiliki sifat kalor timbul yang rendah (Rizuan et al., 2016). Sementara karet SBR dan BR diketahui memiliki keunggulan ketahanan abrasi yang sangat baik (Sae-oui et al., 2017). Perpaduan kedua jenis karet tersebut dengan setiap keunggulannya dinilai sesuai digunakan sebagai base elastomer dalam pembuatan bagian telapak ban kendaraan.

Ban pejal diproduksi untuk memfasilitasi kinerja kendaraan berat seperti kendaraan pengangkat barang (forklift). Pampatan tetap menjadi parameter penting dalam penilaian kualitas ban pejal. Nilai pampatan tetap dapat dianggap sebagai indikator kemampuan ban pejal dalam menahan beban berat (Phromjan \& Suvanjumrat, 2018). Konsumsi ban pejal untuk penggantian pada kendaraan forklift cukup tinggi disebabkan karena bagian telapak ban pejal umumnya cepat aus. Kinerja ban pejal yang sering melakukan gerakan manuver sekaligus dengan membawa beban berat mengakibatkan bagian telapak cepat terkikis. Penggunaan ban pejal vulkanisir menjadi pilihan utama untuk menghemat biaya operasional kendaraan forklift. Telapak ban merupakan bagian terpenting pada konstruksi suatu ban vulkanisir.
Fluktuasi harga karet alam di pasar komoditas global telah berlangsung sejak tahun 2012. Kondisi tersebut memaksa produsen karet alam mencari strategi agar tetap dapat mempertahankan usahanya. Salah satu langkah yang mungkin ditempuh adalah dengan menerapkan manajemen persediaan "buffer stock". Brown (1974) menyatakan bahwa tujuan manajemen buffer stock adalah untuk menstabilkan harga internasional dan pendapatan produsen. Dengan menerapkan manajemen buffer stock, maka banyak karet alam mentah yang disimpan dalam gudang produsen sebelum dilepas ke pasar komoditas.

Masa simpan berpengaruh besar terhadap mutu karet alam SIR 20 terutama sifat viskositas Mooney. Selama masa penyimpanan, antar molekul non karet saling berikatan silang. Mekanisme ini menyebabkan terjadinya storage hardening yang ditandai dengan peningkatan nilai viskositas Mooney (Yunyongwattanakorn et al., 2003). Untuk mengurangi risiko terjadinya storage hardening selama penerapan buffer stock, maka lebih aman menyimpan dalam bentuk karet TSR jenis SIR 3CV (constan viscosity). Karet SIR 3CV yang diolah dari bokar jenis lateks kebun merupakan tipe high grade TSR dan sudah mulai banyak diproduksi oleh crumb rubber factory di dalam negeri. Karet SIR 3CV tidak menunjukkan peningkatan viskositas Mooney meskipun disimpan selama 36 minggu (Sakdapipanich et al., 2007). Dalam perdagangan, SIR 3CV dikategorikan berdasarkan rentang nilai viskositas Mooney yaitu SIR 3CV 50 (Viskositas Mooney ML $\left.(1+4) 100^{\circ} \mathrm{C}: 50 \pm 5\right)$ dan SIR 3CV 60 (Viskositas Mooney ML $\left.(1+4) 100^{\circ} \mathrm{C}: 60 \pm 5\right)$.

Penggunaan karet SIR 3CV sebagai base elastomer secara umum sudah banyak diterapkan di industri manufaktur ban kendaraan bermotor dalam produksi telapak ban maupun komponen struktur ban yang lain. Namun penggunaan karet SIR 3CV dalam pembuatan kompon karet untuk telapak ban vulkanisir belum dievaluasi oleh industri vulkanisir ban. Industri vulkanisir ban banyak menggunakan karet alam jenis RSS1 dan SIR 20. Penelitian ini dimaksudkan untuk mengkaji perbandingan sifat fisika dan mekanik komposit karet alam/karet sintetik yang 
dibuat dari perpaduan antara karet SIR 20/SBR dan karet SIR 3CV/BR dalam pembuatan bagian telapak ban pejal vulkanisir untuk kendaraan forklift. Dengan perpaduan jenis dan komposisi karet alam/karet sintetik yang tepat diharapkan produk yang dihasilkan dari riset ini dapat diaplikasikan di industri ban pejal vulkanisir pada masa mendatang.

\section{BAHAN DAN METODE}

Bahan utama penelitian menggunakan karet alam mentah jenis Standard Indonesian Rubber (SIR) tingkatan mutu SIR 3CV 50 dan SIR 20. Sedangkan jenis karet sintetik yang dipakai dalam eksperimen adalah SBR ex Lanxess dan polybutadiene rubber (BR). Karet SIR 3CV 50 diperoleh dari PT Socfin Indonesia, karet SIR 20 dan BR diperoleh dari UD. Sukses Jaya Rubber, Bogor. Sementara SBR ex Lanxess diperoleh dari PT Multi Citra Chemindonusa, Jakarta. Bahan kimia kompon karet sebagai aditif dalam pembuatan komposit karet telapak ban terdiri atas bahan pengaktif (ZnO dan asam stearat), bahan antioksidasi (TMQ dan 6PPD), bahan antiozon (paraffin wax), bahan pengisi (CB N330), bahan pelunak (minyak aromatik), bahan pencepat (CBS), dan bahan pemvulkanisasi (sulfur). Seluruh bahan kimia karet pada spesifkasi teknis dan diperoleh dari PT Multi Citra Chemindonusa.
Susunan formulasi kompon karet untuk telapak ban pejal disajikan pada Tabel 1 sebagai berikut. Komposisi perpaduan SIR 20/SBR dan SIR 3CV/BR yang diatur pada rasio $75 / 25 ; 70 / 30$; dan $65 / 35$ ini ditetapkan dengan mengacu pada ketentuan formula kompon untuk kendaraan berat. Pada formulasi kompon karet untuk ban kendaraan berat, umumnya dirancang proporsi karet alam lebih besar dibandingkan karet sintetik. Sebelum dilakukan pembuatan kompon, karet alam diuji Viskositas Mooney (SNI 1903-2000).

Pembuatan kompon karet dilakukan menggunakan mesin giling terbuka (merek Berstorf) skala laboratorium berkapasitas 1000 g kompon karet/batch. Prosedur pembuatan kompon dan pencetakan vulkanisat untuk contoh uji mengacu pada ASTM D 3182. Tahap pertama, karet dimastikasi hingga menjadi lunak agar mudah bercampur dengan bahan kimia kompon karet. Urutan penambahan bahan kimia kompon karet diawali dengan bahan pengaktif, bahan antioksidasi dan antiozon, bahan pengisi dan bahan pelunak, kemudian bahan pencepat dan bahan pemvulkanisasi. Setelah seluruh bahan kimia kompon karet selesai ditambahkan ke dalam matriks karet, kompon terus digiling agar terbentuk kompon karet yang homogen. Kompon yang telah terbentuk kemudian disimpan pada suhu kamar selama kurang lebih 20 jam untuk memberikan kesempatan

Tabel 1. Formula kompon karet untuk ban pejal

Table 1. Rubber compound formula for tread solid tire

\begin{tabular}{|c|c|c|c|c|c|c|c|}
\hline \multirow[t]{2}{*}{ No } & \multirow{2}{*}{$\begin{array}{l}\text { Bahan } \\
\text { Material }\end{array}$} & \multicolumn{6}{|c|}{$\begin{array}{l}\text { Dosis (berat seratus karet, bsk) } \\
\text { Dosage (per hundred rubber, phr) }\end{array}$} \\
\hline & & \multicolumn{3}{|c|}{ SIR 20/SBR } & \multicolumn{3}{|c|}{ SIR 3CV/BR } \\
\hline 1 & Karet alam, SIR 20 & 75 & 70 & 65 & - & - & - \\
\hline 2 & Karet sintetik, SBR & 25 & 30 & 35 & - & - & - \\
\hline 3 & Karet alam, SIR 3 CV 50 & - & - & - & 75 & 70 & 65 \\
\hline 4 & Karet sintetik, BR & - & - & - & 25 & 30 & 35 \\
\hline 5 & Bahan pengaktif, $\mathrm{ZnO}$ & 5 & 5 & 5 & 5 & 5 & 5 \\
\hline 6 & Bahan pengaktif, Asam Stearat & 2 & 2 & 2 & 2 & 2 & 2 \\
\hline 7 & Bahan pencepat, CBS & 1,6 & 1,6 & 1,6 & 1,6 & 1,6 & 1,6 \\
\hline 8 & Bahan pemvulkanisasi, Sulfur & 2,2 & 2,2 & 2,2 & 2,2 & 2,2 & 2,2 \\
\hline 9 & Bahan pengisi, CB N330 & 50 & 50 & 50 & 50 & 50 & 50 \\
\hline 10 & Bahan pelunak, minyak aromatik & 12 & 12 & 12 & 12 & 12 & 12 \\
\hline 11 & Bahan antioksidasi, TMQ & 2 & 2 & 2 & 2 & 2 & 2 \\
\hline 12 & Bahan antioksidasi, 6PPD & 2 & 2 & 2 & 2 & 2 & 2 \\
\hline 13 & Bahan antiozon, paraffin wax & 3,5 & 3,5 & 3,5 & 3,5 & 3,5 & 3,5 \\
\hline
\end{tabular}


partikel bahan kimia karet lebih terdispersi dalam matriks karet.

Kompon karet dicuplik sebanyak 50 g untuk pengujian karakteristik vulkanisasi (ASTM D 2084-17) pada Moving Die Rheometer (MDR) merek Alpha 2000 dari Alpha Technologies. Suhu vulkanisasi ditetapkan pada $150^{\circ} \mathrm{C}$. Hasil pengujian karakteristik selanjutnya digunakan sebagai acuan dalam menetapkan kondisi pencetakan kompon menjadi vulkanisat sampel uji menggunakan mesin cetak hidrolik merek Hirara \& Co Ltd. Pengujian sifat fisika dan mekanik vulkanisat telapak ban pejal meliputi parameter kekerasan (Frank Durometer, ASTM D 2240), kuat tarik (UTM Llyod 2000R, ASTM D 412), perpanjangan putus (UTM Llyod 2000R, SNI ISO 37:2015), ketahanan retak lentur (Flexometer, ASTM D 430-06), ketahanan sobek (UTM Instron, ASTM D 624-00), ketahanan ozon (ASTM D 1149-16), dan pengusangan yang dipercepat (accelerated aging, ASTM D 573-04). Kondisi pada pengujian ketahanan ozon dalam ozone test chamber ditetapkan pada $25 \mathrm{pphm}, 72$ jam, $20 \%$ regangan. Sementara kondisi uji pengusangan yang dipercepat dilakukan pada $70^{\circ} \mathrm{C}$ selama 168 jam. Parameter kekerasan, kuat tarik dan perpanjangan putus diuji pada kondisi sebelum dan setelah pengusangan.

\section{HASIL DAN PEMBAHASAN}

Analisis karakteristik vulkanisasi kompon karet memberikan informasi mengenai modulus torsi (maksimal, minimal, dan selisih) serta waktu (pravulkanisasi dan vulkanisasi optimal). Hasil dari pengukuran modulus torsi dan waktu pada saat analisis karakteristik vulkanisasi disajikan pada Gambar 1 dan 2 . Modulus torsi minimal (ML) mengindikasikan kemampuan proses dan viskositas kompon karet, sedangkan modulus torsi maksimal ( $\mathrm{MH}$ ) terkait dengan kekakuan dan modulus geser dari vulkanisat karet. Sementara nilai selisih $\mathrm{MH}$ dan ML menggambarkan besarnya derajat ikatan silang antar molekul karet (Formela et al., 2015). Waktu pravulkanisasi diukur pada 2 unit di atas waktu pada saat tercapai modulus torsi minimal, sedangkan waktu vulkanisasi optimal dihitung ketika tercapai 90\% dari modulus torsi maksimal (ElSabbagh \& Yehia, 2007). Sifat rheologi dan mekanik perpaduan karet bergantung pada jenis base elastomer, tipe dan jumlah bahan kimia karet serta kondisi lingkungan (Burgaz et al., 2019).

Dari Gambar 1 terlihat bahwa perpaduan karet SIR 3CV/BR memiliki nilai selisih modulus torsi yang cenderung lebih tinggi dibandingkan dengan perpaduan SIR

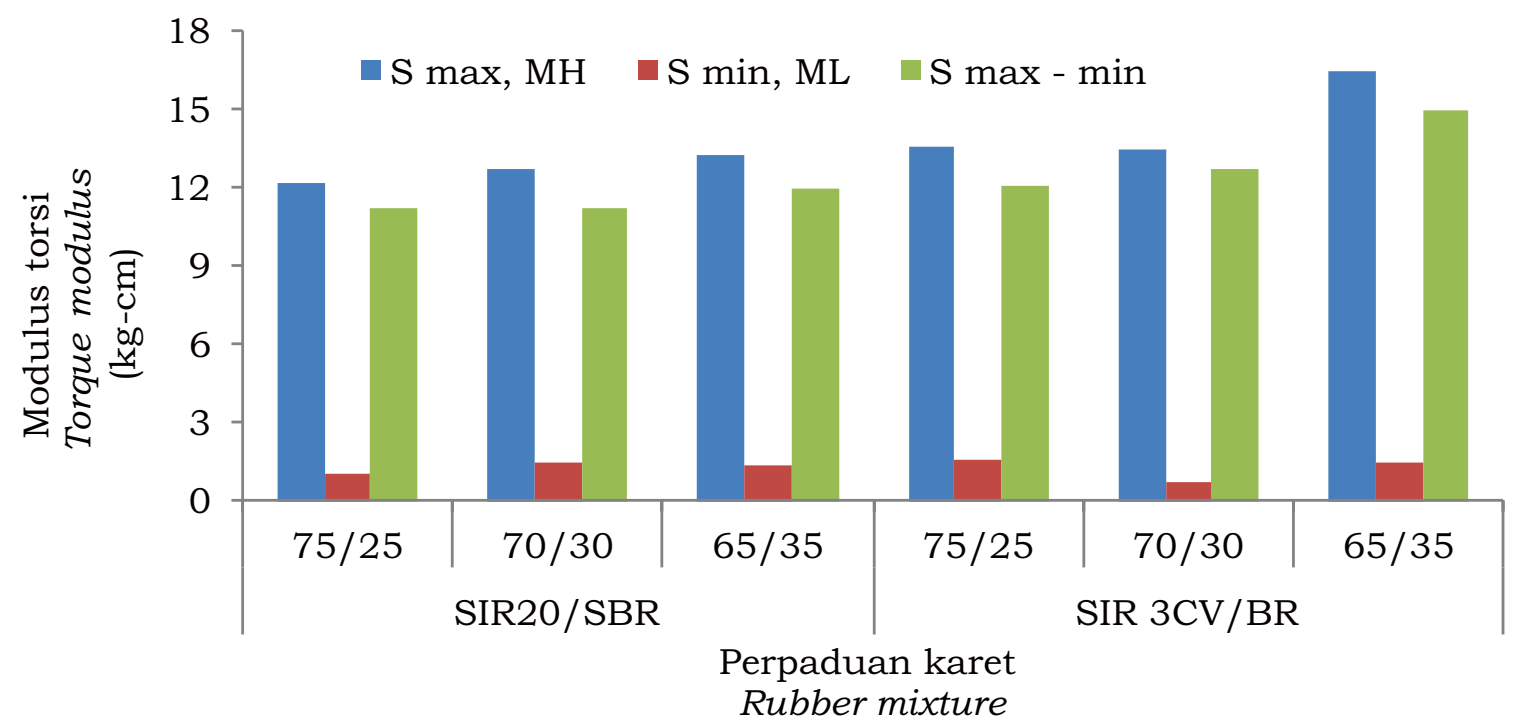

Gambar 1. Modulus torsi pada pengujian karakteristik vulkanisasi kompon

Figure 1. Torque modulus at curing characteristic analysis of rubber compound 
20/SBR. Nilai selisih modulus torsi pada perpaduan karet dalam riset ini lebih ditentukan oleh jenis karet alam yang digunakan. Karet SIR 3CV diolah dari bokar jenis lateks kebun, sedangkan SIR 20 diolah dari bokar jenis koagulum lapangan. Lateks kebun memiliki susunan rantai molekul karet cis 1-4 poliisoprena yang panjang akibatnya menghasilkan modulus torsi yang besar. Sementara struktur rantai molekul pada koagulum lapangan sudah banyak terputus secara mekanis pada saat pengolahan koagulum lapangan menjadi SIR 20 sehingga nilai modulus torsi menjadi lebih rendah.

Gambar 2 memperlihatkan bahwa waktu pravulkanisasi dan waktu vulkanisasi optimal pada perpaduan karet SIR 3CV/BR relatif lebih cepat daripada karet SIR 20/SBR. Jumlah ikatan rangkap $(C=C)$ dalam struktur rantai molekul karet alam pada SIR 3CV yang belum terputus dan lebih banyak daripada struktur rantai SIR 20 berperan penting pada berlangsungnya mekanisme reaksi vulkanisasi. Peran molekul $\mathrm{C}=\mathrm{C}$ semakin nyata karena dalam sistem vulkanisasi untuk seluruh perpaduan karet menggunakan sistem vulkanisasi (rasio bahan pencepat dan bahan pemvulkanisasi) yang ditetapkan sama. Adanya kandungan $\mathrm{C}=\mathrm{C}$ yang lebih banyak menjadikan perpaduan karet SIR $3 \mathrm{CV} / \mathrm{BR}$ lebih reaktif yang kemudian diikuti dengan laju reaksi vulkanisasi yang lebih cepat dan waktu vulkanisasi yang lebih singkat dibandingkan perpaduan SIR 20/SBR.

Sifat fisika dan mekanik dari suatu produk karet secara langsung berpengaruh terhadap kinerja dari produk karet tersebut. Oleh karena itu, pengujian sifat fisika dan mekanik produk karet menjadi faktor penting dalam pengembangan produk karet. Perubahan sifat fisik dan mekanik produk karet yang dipicu oleh pengaruh panas dan pengusangan patut untuk dipertimbangkan pada saat perancangan formula kompon dalam pembuatan produk karet (Moon et al., 2018). Selain karena pengaruh panas, perubahan sifat produk karet juga dapat diinisiasi oleh kondisi kelembapan lingkungan, bahan pengotor, beban mekanis, iradiasi, dan kontaminasi bahan kimia (Yahya et al., 2011).

Parameter utama dalam penilaian sifat fisika dan mekanik produk karet meliputi kekerasan dan sifat tarik (kuat tarik dan perpanjangan putus). Tingkatan nilai kekerasan dan sifat tarik ditentukan oleh struktur jalinan dan jenis ikatan silang yang menyusun produk karet tersebut (Zhao et al., 2011). Pada eksperimen ditetapkan komposisi karet alam lebih besar daripada karet sintetik, sehingga sifat fisik dan mekanik perpaduan karet lebih ditentukan oleh sifat asli (origin property) dari karet alam

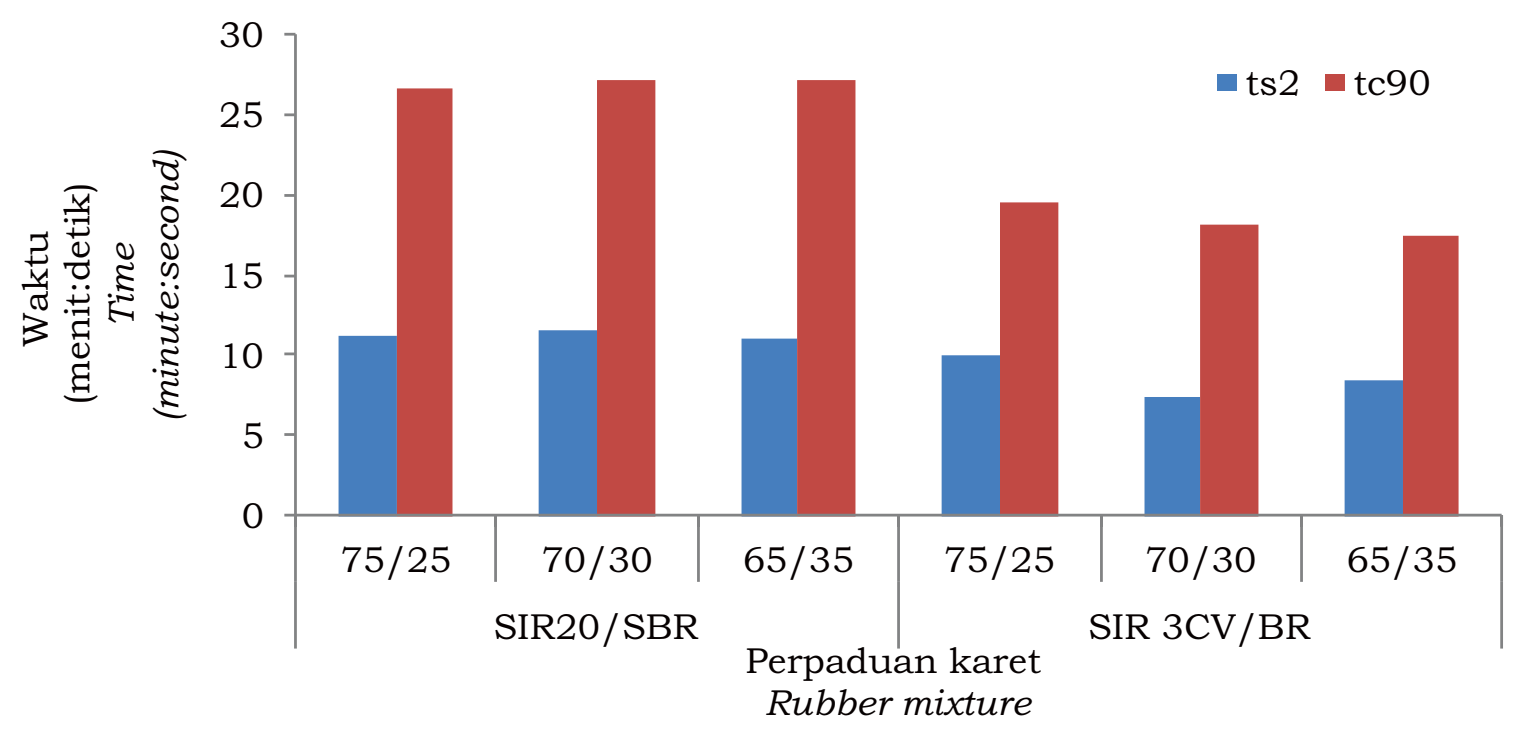

Gambar 2. Waktu pada pengujian karakteristik vulkanisasi kompon

Figure 2. Time at curing characteristic analysis of rubber compound 
(Chiu \& Tsai, 2006). Hasil pengujian ketiga sifat tersebut pada kondisi sebelum dan setelah pengusangan secara berurutan ditampilkan pada Gambar 3, 4, dan 5. Paparan radikal bebas saat kondisi pengusangan pada sampel uji vulkanisat karet telapak ban dapat menyebabkan terjadinya pemutusan rantai molekul, pembentukan ikatan silang namun dapat juga pemutusan ikatan silang. Produk karet yang mengalami pengusangan ditandai dengan menjadi keras namun rapuh dan kehilangan kemampuan peredamannya (Choi et al., 2005).

Selain oleh derajat ikatan silang, sifat fisika dan mekanik perpaduan karet juga turut ditentukan oleh parameter kelarutan. Parameter kelarutan digunakan sebagai indikator untuk mengetahui kompatibilitas antar karet yang saling dicampurkan. Apabila antar karet memiliki kesamaan nilai parameter kelarutan maka antar karet tersebut saling sesuai dan dapat menghasilkan perpaduan karet yang homogen (Jovanovic et al., 2019). Karet alam dan SBR tergolong sebagai polimer non polar dan memiliki parameter kelarutan yang saling berdekatan sehingga dapat membentuk perpaduan karet yang homogen (Tinker \& Jones, 1998). Kompatibilitas antar perpaduan karet yang baik akan memberikan sifat fisika dan mekanik yang unggul pada perpaduan karet tersebut.

Tingkat kekerasan vulkanisat karet yang dihasilkan dari perpaduan karet SIR 20/SBR berada pada rentang 55-57 Shore A sebelum pengusangan kemudian menjadi 58-60 Shore A setelah pengusangan. Sedangkan pada perpaduan karet SIR 3CV/BR dari rentang 54-55 menjadi 57-58. Perpaduan SIR 20/SBR memiliki tingkat kekerasan sedikit lebih tinggi dibandingkan SIR 3CV/BR. Nilai kekerasan yang tinggi pada perpaduan SIR 20/SBR diperkirakan karena karet SIR 20 yang digunakan telah mengalami perkerasan yang dipercepat. Berdasarkan hasil uji Viskositas Mooney diperoleh nilai ML $1+4100^{\circ} \mathrm{C}$ SIR 20 sebesar 100,2 dan SIR 3CV sebesar 67,4. Selain itu adanya kandungan kopolimer stirena dan butadiene dalam rantai molekul SBR turut berkonstribusi dalam peningkatan nilai kekerasan perpaduan SIR 20/SBR (Findik et al., 2004).
Peningkatan nilai kekerasan sebesar 3 unit setelah pengusangan yang dipercepat menunjukkan bahwa perpaduan karet SIR 20/SBR dan SIR 3CV/BR mampu menahan paparan oksigen selama kondisi pengujian pengusangan yang dipercepat. Ketika pengujian pengusangan yang dipercepat, terjadi dua mekanisme reaksi yaitu pembentukan ikatan silang dan pemutusan ikatan rangkap $\mathrm{C}=\mathrm{C}$ oleh atom oksigen. Terjadinya pembentukan ikatan silang diindikasikan oleh berkurangnya fleksibilitas pergerakan rantai molekul karet yang diikuti oleh naiknya level kekerasan vulkanisat karet (Hinchiranan et al., 2008; Arayapranee \& Rempel, 2009). Mekanisme kedua yaitu atom oksigen menyerang bagian permukaan vulkanisat karet dan secara bertahap menembus ke bagian dalam. Atom oksigen memutus ikatan rangkap $\mathrm{C}=\mathrm{C}$ yang belum membentuk ikatan silang ketika reaksi vulkanisasi menjadi ikatan jenuh tunggal C-C, serta ikatan C-C, C-S-C, C-S-S$\mathrm{C}$, dan $\mathrm{C}-\mathrm{S}_{\mathrm{x}}-\mathrm{C}$ pada struktur ikatan silang karet. Pada eksperimen ini, mekanisme pertama lebih dominan daripada mekanisme kedua.

Pada komposisi yang sama, perpaduan SIR 20/SBR memberikan nilai kuat tarik yang lebih besar daripada perpaduan SIR 3CV/BR. Namun pada perpaduan yang sama dengan bertambahnya proporsi karet sintetik justru menurunkan kuat tarik. Hasil pengujian tersebut sejalan dengan hasil penelitian Chiu \& Tsai (2006) yang menyatakan bahwa kuat tarik dan ketahanan sobek perpaduan NR/BR meningkat seiring dengan bertambahnya dosis karet alam. Hasil riset Jovanovic et al. (2019) juga menunjukkan bahwa sifat tarik perpaduan karet turun dengan bertambahnya kadar SBR. Karet sintetik SBR dan BR bersifat amorf, sehingga pada saat direnggangkan tidak terjadi kristalisasi. Sementara pada karet alam yang direnggangkan maka molekulnya akan mengalami kristalisasi (strain induced cryatalization) (Findik et al., 2004). Terjadinya kristalisasi pada molekul karet alam mengakibatkan nilai kuat tarik menjadi tinggi karena diperlukan tenaga yang besar untuk memutus rantai tersebut. Dengan bertambahnya komposisi karet sintetik dalam paduan karet maka akan menambah kandungan bahan amorf dalam paduan tersebut yang diikuti dengan 
Komparasi Perpaduan SIR 20/SBR dan SIR 3CV/BR sebagai Base Elastomer terhadap Karakteristik Komposit Karet untuk Telapak Ban Pejal Vulkanisir

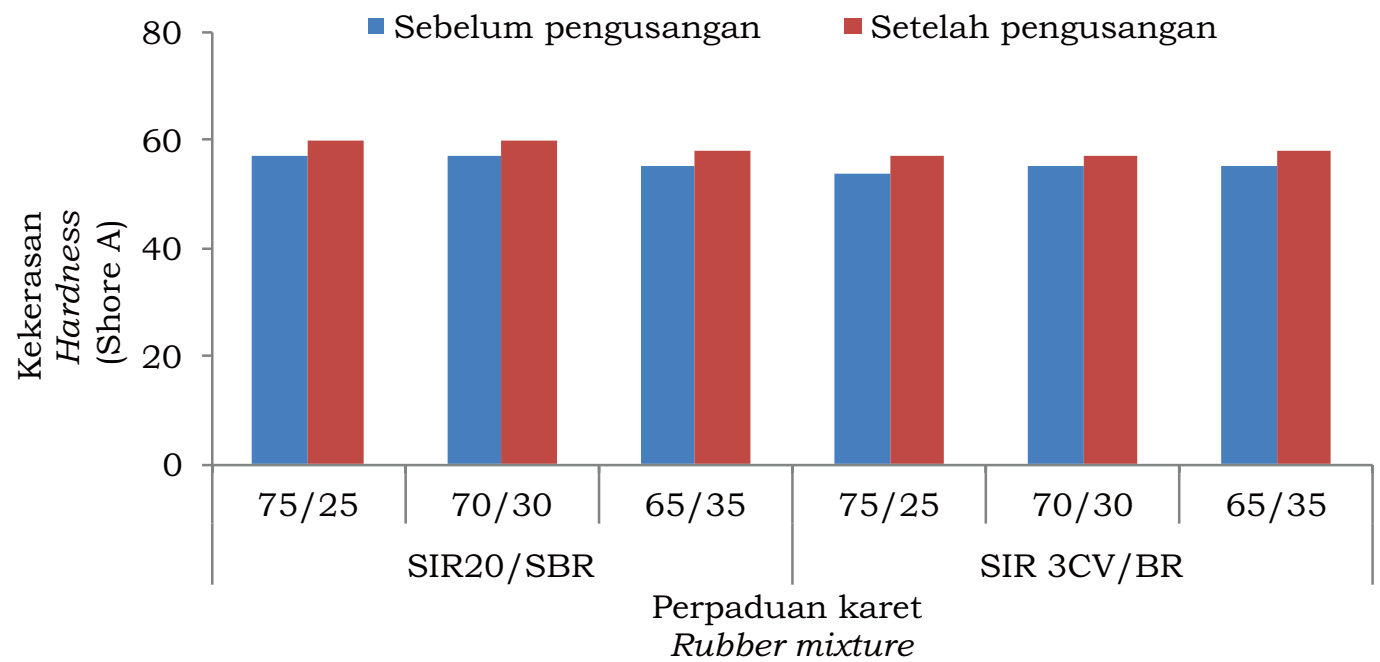

Gambar 3. Kekerasan vulkanisat telapak ban pejal

Figure 3. Hardness of vulcanized solid tire tread

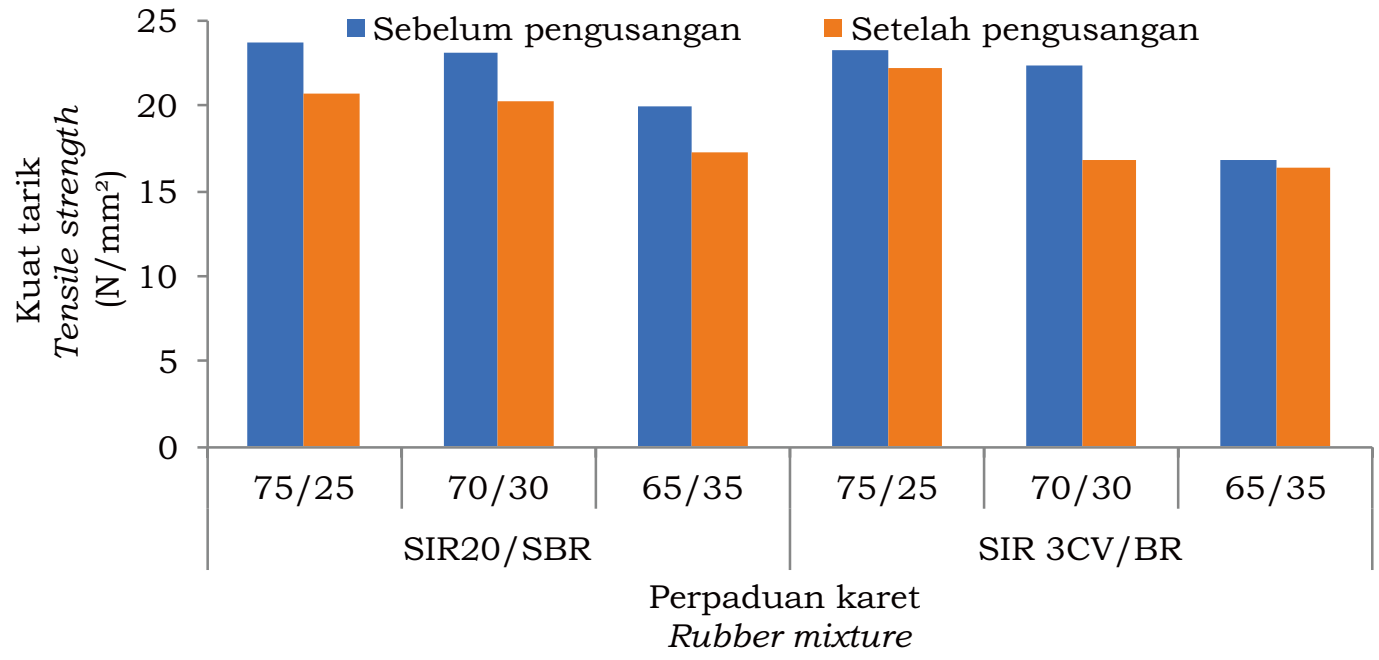

Gambar 4. Kuat tarik vulkanisat telapak ban pejal

Figure 4. Tensile strength of vulcanized solid tire tread

penurunan sifat kuat tarik. Gambar 4 memperlihatkan bahwa kuat tarik perpaduan karet setelah pengusangan mengalami penurunan. Kondisi pengusangan mengakibatkan naiknya kekakuan struktur rantai molekul karet yang pada akhirnya membatasi pergerakkan rantai molekul karet tersebut serta menurunkan kuat tarik dari vulkanisat paduan karet (Liu et al., 2016).
Secara umum hasil pengujian perpanjangan putus yang disajikan pada Gambar 5 mengindikasikan bahwa bertambahnya komposisi karet sintetik dalam perpaduan karet NR/SR yang digunakan dalam pembuatan telapak ban pejal menyebabkan penurunan nilai perpanjangan putus. Temuan ini terkonfirmasi dengan hasil riset Doma \& Hassan (2017) yang mengemukakan bahwa 


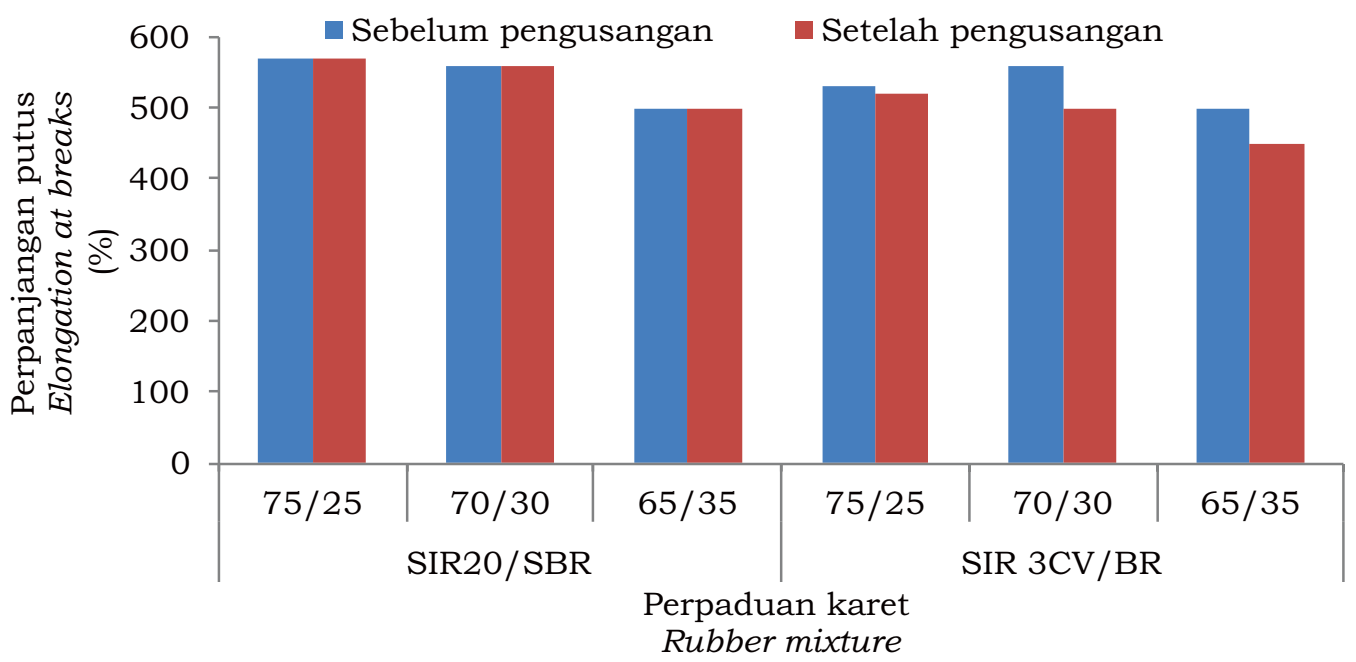

Gambar 5. Perpanjangan putus vulkanisat telapak ban pejal

Figure 5. Elongation at breaks of vulcanized solid tire tread

sifat tarik perpaduan karet meningkat seiring dengan bertambahnya komposisi NR. Pada komposisi NR/SR yang sama, perpaduan SIR 20/SBR memberikan nilai perpanjangan putus relatif sedikit di atas perpaduan SIR 3CV/BR. Perpanjangan putus perpaduan karet bergantung pada struktur mikro rantai molekul (perpanjangan rantai lurus dan percabangan) perpaduan karet. Struktur rantai molekul perpaduan SIR 20/SBR diperkirakan membentuk percabangan lebih banyak dibandingkan dengan perpaduan SIR 3CV/BR, akibatnya menghasilkan sifat perpanjangan putus yang lebih tinggi. Banyaknya rantai cabang yang saling berikatan silang, menyebabkan semakin besar tenaga yang diperlukan untuk dapat memutus rantai tersebut. Sejalan dengan hasil pengujian kuat tarik, nilai perpanjangan putus vulkanisat telapak ban pejal yang terbuat dari perpaduan karet SIR $3 \mathrm{CV} / \mathrm{BR}$ cenderung mengalami penurunan setelah kondisi pengusangan yang dipercepat. Namun nilai perpanjangan putus vulkanisat yang terbuat dari perpaduan SIR 20/SBR tidak mengalami perubahan. Penurunan perpanjangan putus dapat disebabkan dari terputusnya rantai molekul karet akibat paparan oksigen saat pengusangan. Pada karet SIR 3CV relatif masih banyak mengandung ikatan rangkap $\mathrm{C}=\mathrm{C}$ yang rentan terputus akibat diserang oleh oksigen. Tingginya ikatan rangkap pada karet SIR $3 \mathrm{CV}$ disebabkan karena menggunakan bahan baku lateks kebun.
Parameter ketahanan sobek menjadi salah satu tolak ukur dalam menentukan mutu telapak ban pejal vulkanisir. Telapak ban merupakan lapisan terluar dari suatu ban yang bergesekan dengan permukaan jalan sehingga rentan mengalami cacat sobek apabila tergores atau terbentuk pada permukaan yang keras dan kasar. Ketahanan sobek dari vulkanisat karet yang besarnya dipengaruhi oleh tingkat derajat ikatan silang memberikan gambaran tentang ketahanan karet terhadap perambatan retak (crack propagation) (Mohammad \& Simon, 2006; Thongpin et al., 2010). Hasil pengujian ketahanan sobek vulkanisat tapak ban pejal ditampilkan pada Gambar 6. Dari Gambar 6 terlihat bahwa nilai ketahanan sobek telapak ban dari perpaduan SIR20/SBR lebih rendah dibandingkan telapak ban yang dihasilkan dari perpaduan SIR 3CV/BR. Ketahanan sobek vulkanisat karet juga berkaitan dengan derajat ikatan silang. Derajat ikatan silang diindikasikan dari nilai MH-ML. Ditinjau dari Gambar 1, terlihat bahwa kombinasi SIR 20/SBR 75/25 menghasilkan nilai MH-ML yang paling rendah dibandingkan dengan kombinasi lainnya yang berpengaruh terhadap nilai ketahanan sobeknya yang rendah. Nilai ketahanan sobek vulkanisat SIR 20/SBR 75/25 dapat diperbaiki dengan melakukan reformulasi dengan pengaturan dosis bahan pengisi. 


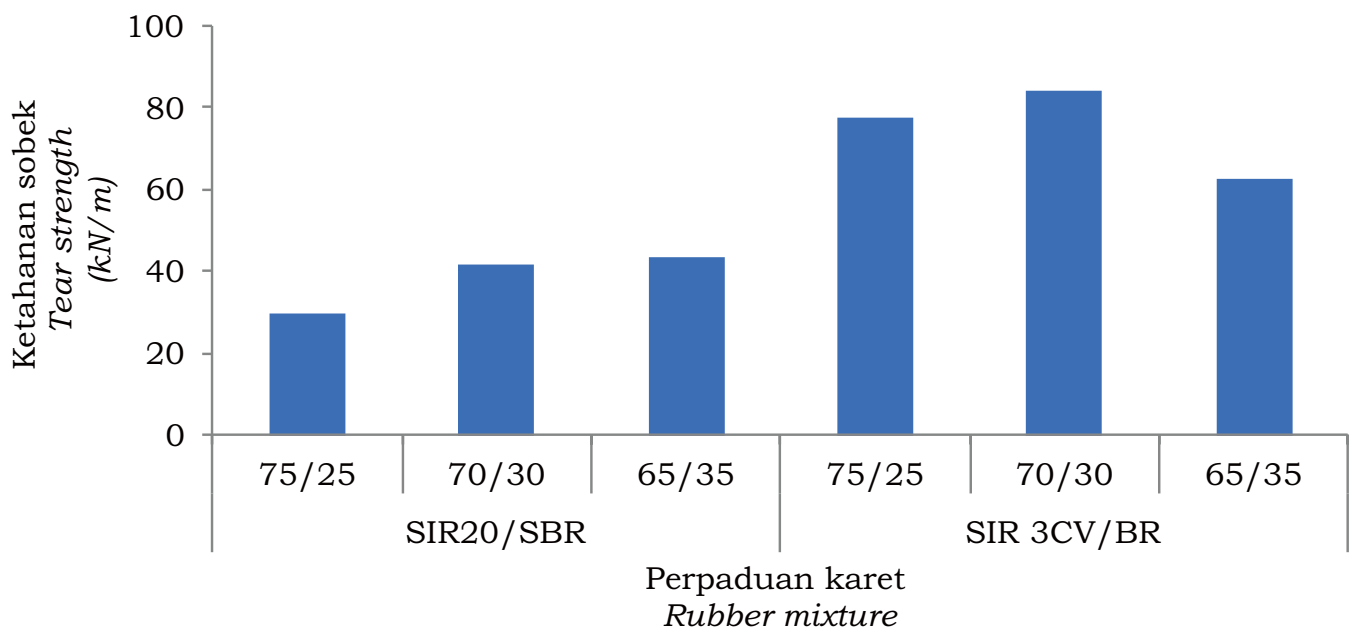

Gambar 6. Ketahanan sobek vulkanisat telapak ban pejal

Figure 6. Tear strength of vulcanized solid tire tread

Parameter ketahanan retak lentur mengindikasikan kemampuan karet dalam menahan sejumlah siklus pelenturan yang terjadi secara berulang tanpa mengalami retakan permukaan akibat tegangan. Ketahanan retak lentur merupakan suatu indeks untuk mengukur ketahanan fatik material karet. Parameter ketahanan retak lentur menjadi penting dalam penilaian mutu vulkanisat karet untuk telapak ban karena dapat digunakan sebagai indikator awal terjadinya kegagalan fungsi akibat cacat retak pada permukaan ban yang disebabkan oleh tegangan mekanis (ElSabbagh et al., 2001). Hasil pengujian ketahanan retak lentur vulkanisat perpaduan karet SIR 20/SBR dan SIR 3CV/BR untuk telapak ban pejal yang dinyatakan dalam kilocycles $(\mathrm{kCs})$ disajikan pada Gambar 7. Dari Gambar 7 dapat diketahui bahwa ketahanan retak lentur terbaik dihasilkan dari perpaduan karet SIR 20/SBR 70/30 dan SIR 3CV/BR 65/35.

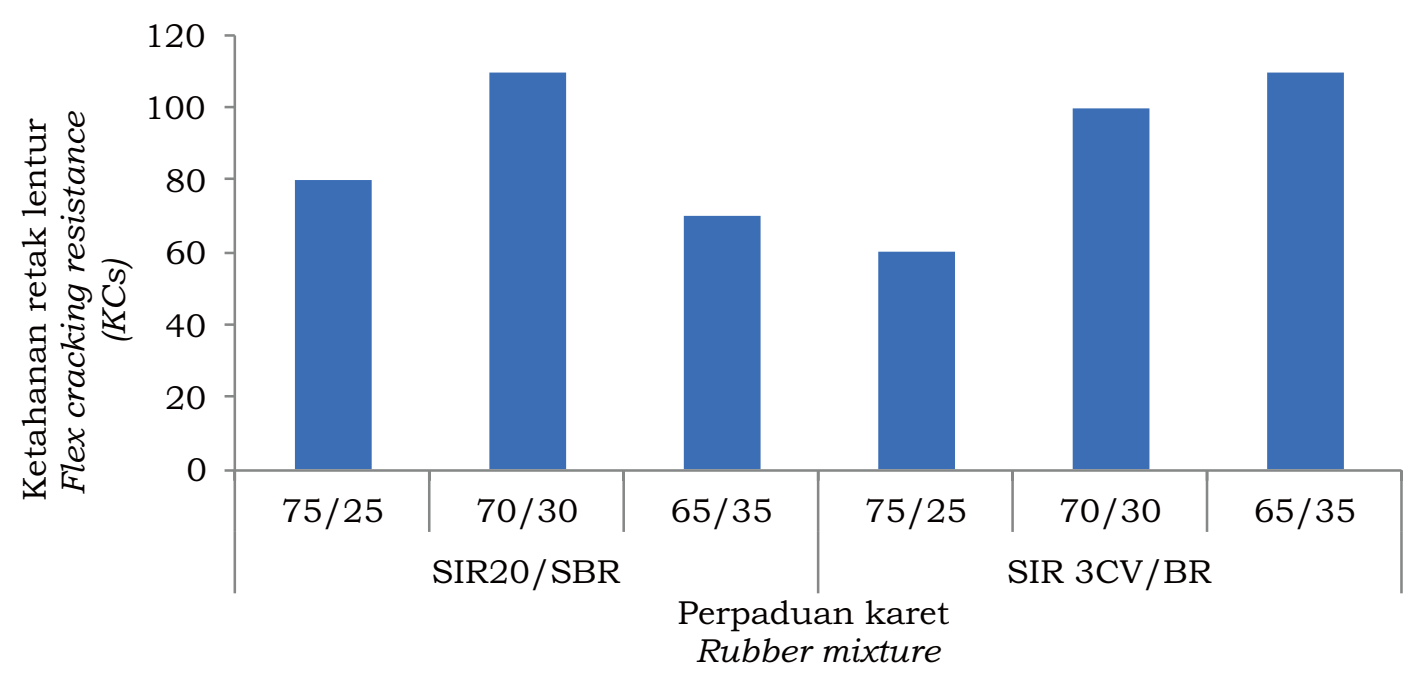

Gambar 7. Retak lentur vulkanisat telapak ban pejal

Figure 7. Flex cracking of vulcanized solid tire tread 
Terjadinya retakan permukaan ban pejal selain akibat cyclic loading juga dapat disebabkan oleh ozone cracking. Atom ozon dapat sangat reaktif bereaksi dengan bagian tak jenuh (ikatan rangkap) pada rantai molekul karet yang belum mengalami ikatan silang saat reaksi vulkanisasi (Tse, 2007). Serangan ozon pada ikatan rangkap molekul karet dapat ditangkal dengan penggunaan bahan antiozonan. Pengujian ketahanan ozon merupakan analisis kualitatif yang dilakukan dengan mengamati ada atau tidaknya retakan pada permukaan vulkanisat karet setelah terpapar oleh ozon pada waktu dan konsentrasi tertentu. Hasil pengujian ketahanan ozon pada vulkanisat telapak ban pejal baik yang terbuat dari perpaduan SIR 20/SBR maupun SIR 3CV/BR tidak menunjukkan adanya retakan pada permukaan vulkanisat kedua jenis perpaduan karet tersebut.

\section{KESIMPULAN}

Kesimpulan yang dapat ditarik berdasarkan hasil eksperimen dan pengujian yang telah dilakukan adalah bahwa perpaduan karet alam dan karet sintetik jenis SIR 20/SBR memiliki kinerja yang lebih baik sebagai base elastomer dalam pembuatan telapak ban pejal untuk roda forklift vulkanisir dibandingkan dengan perpaduan karet jenis SIR 3CV/BR. Rasio SIR 20/SBR sebesar 75/25 dianggap sebagai komposisi terbaik pada formulasi kompon karet untuk telapak ban karena didukung dengan hasil pengujian sifat fisika dan mekanik yang terbaik meliputi kekerasan (57 Shore A), kuat tarik $(23,77$ $\left.\mathrm{N} / \mathrm{mm}^{2}\right)$, dan perpanjangan putus $(570 \%)$. Namun nilai ketahanan sobek $(29,7 \mathrm{kN} / \mathrm{m})$ dan ketahan retak lentur $(80 \mathrm{kCs})$ pada perpaduan karet tersebut masih perlu dtingkatkan.

\section{KONSTRIBUSI PENULIS}

Penyusun konsep penelitian (Adi Cifriadi, Santi Puspitasari, dan Norma Arisanti Kinasih), pelaksanaan eksperimen dan pengumpulan data hasil pengujian (Norma Arisanti Kinasih, Nurjannah, dan Novi Widianti), pengolahan/intepretasi data dan penulisan naskah publikasi (Santi Puspitasari), proses publikasi naskah (Santi
Puspitasari). Pembagian peran : Konstributor Utama (Santi Puspitasari dan Norma Arisanti Kinasih), Kontributor Anggota (Adi Cifriadi, Nurjannah, dan Novi Widianti). Penelitian dilaksanakan dalam supervisi oleh Adi Cifriadi dan Santi Puspitasari.

\section{UCAPAN TERIMA KASIH}

Seluruh Penulis mengucapkan terima kasih dan memberikan penghargaan tinggi kepada Kementerian Riset dan Teknologi/BRIN atas bantuan dana riset melalui Program Insentif Inovasi Teknologi yang Dimanfaatkan di Industri TA 2019 ( $\mathrm{K}$ o n t r a k R i s e t $\mathrm{N}$ o m o r 29 / PPK/SK/INDUSTRI-DII / IV / 20 19). Ucapan terima kasih turut disampaikan pula kepada para Tenaga Teknisi Penelitian, Teknisi Pabrik Percobaan, dan Analisis Laboratorium Pengujian Balai Penelitian Teknologi Karet Pusat Penelitian Karet atas konstribusi selama pelaksanaan kegiatan penelitian.

\section{DAFTAR PUSTAKA}

Arayapranee, W., \& Rempel, G.L. (2009). Synthesis and mechanical properties of diimide hydrogenated natural rubber vulcanizates. Journal of Applied Polymer Science, 114, 40664075.https://doi.org/10.1002/app.31132

Brown, C.P. (1974). International commodity control through national buffer stocks: A case study of natural rubber. The Journal of Development Studies, 10(2), 188-212. http://dx.doi.org/10.1080/002203 87408421484

Burgaz, E., Gencoglu, O., \& Goksuzoglu, M. (2019). Carbon black reinforced natural rubber/butadiene rubber and natural rubber/butadiene rubber/stirene-butadiene rubber composite: Part I: Rheological, mechanical and termomechanical properties. Research on Engineering Structures \& Materials, 5(3), 233-247. http://dx.doi.org/10.17515/resm20 19.74 ma 1123 
Chiu, H.T., \& Tsai, P.A. (2006). Aging and mechanical properties of NR/BR blends. Journal of Material Engineering and Performance, 15,88-94. https://doi.org/10.1361/105994906X83 448

Choi, J.H., Kang, H.J., Jeong, H.Y., Lee, T.S., \& Yoon, S.J. (2005). Heat aging effects on the material property and the fatique life of vulcanized natural rubber fatique life prediction equations. Journal of Mechanical Science and Technology, 19(6), 12291242.https://doi.org/10.1007/BF02984044

Doma, A.S., \& Hassan, H.H. (2017). Curing parameters and mechanical properties of NR/SBR blends. American Journal of Condensed Matter Physics, 7(4), 87-92. https://doi.org/10.5923/j.ajcmp.20 170704.02

El-Sabbagh, S.H., Ismail, M.N., \& Yehia, A.A. (2001). Effect of the curing system on the fatique behaviour of NR vulcanizate. Journal of Elastomer and Plastics, 33, $263-281$. https://doi.org/10.1106\%2F6BTKNRF2-140X-LNT2

El-Sabbagh, S.H., \& Yehia, A.A. (2007). Detection of crosslink density by different methods for natural rubber blended with SBR and NBR. Egypt Journal of Solids, 30(2), 157-173. Corpus ID: 702229.

Findik, F., Yilmaz, R., \& Koksal, T. (2004). Investigation of mechanical and physical propertis of several industrial rubbers. Materials and D e sign, $25,269-276$. https://doi.org/10.1016/j.matdes.2 003.11.003
Formela, K., Wasowicz, D., Formela, M., Hejna, A., \& Haponiuk, J. (2015). Curing characteristic, mechanical and thermal properties of reclaimed ground tire rubber cured with various vulcanizing system. Iranian Polymer Jo u r n a l, 24, 289 - 297 . https://doi.org/10.1007/s 13726 015-0320-9

Gould, H. (2015). The journey towards more sustainable rubber leads to Russian dandelions. Circular Economy Guardian Sustainable Business. 6 Nov 2015. https://www.theguardian.com/sustaina ble-business / 2015/nov/06/rubbertires-rus sian-d andelion ssustainability-timberland-shoeswaste

Hinchiranan, N., Lertweerasirikun, W., Poonsawad, W., Rempel, G.L., \& Prasassarakich, P. (2008). Cure characteristic and mechanical properties of hydrogenated natural rubber/natural rubber blends. Journal of Applied Polymer Science, $111, \quad 2813-2821$. https://doi.org/10.1002/app.29333

Jovanovic, S., Jovanovic, V., Markovic, G., Samarzija-Jovanovic, S., Milicevic, Z., Marinovic-Cincovic, M., \& Budinski-Simendic, J. (2019). Elastomer based on NR/BR/SBR ternary rubber blend: morphological, mechanical, and thermal properties. Chemical Industry and Chemical Engineering, 25(1), 31-38. http:/ /dx.doi.org/ 10.2298/CICEQ1 $71106016 \mathrm{~J}$

Liu, J., Li, X., Xu, L., \& Zhang, P. (2016). Invenstigation of aging behaviour and mechanism of nitrile-butadiene rubber (NBR) in the accelerated thermal aging environment. Polymer Testing, $54,59-66$. https://doi.org/10.1016/j.polymert esting.2016.06.010 
Mohammad, A., \& Simon, G.P. (2006). Rubber Clay Composite. Cambridge, UK: Woodhead Publishing Ltd. https://doi.org/10.1533/97818456 91127.1.297

Moon, B., Lee, J., Park, S., \& Seok, C.S. (2018). Study on the aging behaviour of natural rubber/butadiene rubber (NR/BR) blends using a parallel spring model. Polymers, 10, 658-667. https://doi.org/10.3390/polym 100 60658

Phromjan, J., \& Suvanjumrat, C. (2018). Material properties of natural rubber solid tires for finite element analysis. Key Engineering Materials, 775, 5605

https://doi.org/10.4028/www.scien tific.net/KEM.775.560

Rizuan, M.I.R., Wahab, M.A.A., \& Romli, A.Z. (2016). Effect of carbon black structures towards heat build-up measurements and its dynamic properties. Advanced Material Research, 1134, 11-137. https://doi.org/10.4028/www.scien tific.net/AMR.1134.131

Sae-oui, P., Suchiva, K., Sirisinha, C., Intiya, W., Yodjun, P., \& Thepsuwan, U. (2017). Effects of blend ration and SBR type on properties of carbon black-filled and silica-filled SBR/BR tire tread compounds. Advanced in Materials Science and Engineering,

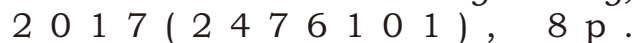
https://doi.org/10.1155/2017/247 6101

Sakdapipanich, J.T., Chanmanit, A., \& Suchiva, K. (2007). Processing properties of various grades of Thai natural rubber. Raw Materials and Applications, (Juli/Agustus 2007), 380-388.
Thongpin, C., Niltui, P., Sornwaneenawakhun, P., Maneeprom, T., Malithong, S., \& Wimolmala, E. (2010). Cure characteristic and mechanical properties of epoxidized natural rubber/chloroprene (ENR/CR) blends. Advanced Materials Research, 93-94, 631-634. https://doi.org/10.4028/www.scien tific.net/AMR.93-94.631

Tinker, A.J., \& Jones, K.P. (1998). Blends of natural rubber: novel techniques for blending with specialty polymers. London, UK: Chapman \& Hall.

Tse, M.F. (2007). Ozone cracking and flex cracking of crosslinked polymer blend compound. Journal of Applied Polymer Science, 103(4), 2183-2196. https://doi.org/10.1002/app.25139

Yahya, Y.S.R., Azura, A.R., \& Ahmad, Z. (2011). Effect of curing system on thermal degradation behaviour of natural rubber (SMR CV 60). Journal of Physical Science, 22(2), 1-14. https://doi.org/10.13140/RG.2.1.1 419.5683

Yunyongwattanakorn, J., Tanaka, Y., Kawahara, S., Klinklai, W., \& Sakdapipanich, J. (2003). Effect of non rubber components on storage hardening and gel formation of natural rubber during accelerated storage under various conditions. Rubber Chemistry and Technology, 76(5), 1228-1240. https://doi.org/ $10.5254 / 1.3547799$

Zhao, F., Bi, W., \& Zhao, S. (2011). Influence of crosslink density on mechanical properties of natural rubber vulcanizates. Journal of Macromolecular Science, Part B: Physics, 50, 1460-1469. https:// doi.org/10.1080/00222348.2010.50 7453 